in vivo $34: 2973-2980(2020)$

doi:10.21873/invivo.12128

\title{
Identification of Patients at High Risk for Postsurgical Hypoparathyroidism
}

\author{
KASSIANI KAKAVA ${ }^{1}$, SYMEON TOURNIS $^{2}$, KONSTANTINOS MAKRIS $^{3}$, GEORGIOS PAPADAKIS $^{4}$, \\ EVANTHIA KASSI ${ }^{5}$, ISMENE DONTAS $^{2}$ and THEODORE KARATZAS ${ }^{6}$ \\ ${ }^{1}$ Head and Neck Surgery Department of Metaxa Anti-Cancer Hospital, Pireaus, Greece; \\ ${ }^{2}$ Laboratory for the Research of the Musculoskeletal System "Th. Garofalidis", School of Medicine, \\ National and Kapodistrian University of Athens, KAT Hospital, Athens, Greece; \\ ${ }^{3}$ Department of Clinical Biochemistry, KAT General Hospital, Athens, Greece; \\ ${ }^{4}$ STEPS Stoffwechselzentrum, Biel/Bienne, Switzerland; \\ ${ }^{5}$ Endocrinology Unit, National and Kapodistrian University of Athens, Laiko General Hospital, Athens, Greece; \\ ${ }^{6} 2^{\text {nd }}$ Propaedeutic Department of Surgery, National and Kapodistrian \\ University of Athens, Laiko General Hospital, Athens, Greece
}

\begin{abstract}
Background/Aim: Postsurgical hypoparathyroidism (PostHypo) is a common complication after total thyroidectomy. We studied the risk factors associated with PostHypo. Patients and Methods: The study included 109 women, (mean age: $50.7 \pm 10.75$ years), who underwent total thyroidectomy for thyroid diseases. Results: Based on the development of biochemical hypocalcemia on the first postoperative day following total thyroidectomy, (c Ca<8.4 $\mathrm{mg} / \mathrm{dl}$ ), 37 women developed PostHypo and 72 did not. Younger age, a lower preoperative corrected calcium and the presence of parathyroid glands in the specimens were related to the development of PostHypo. Of all patients, $51.4 \%$ had a vitamin $D$ deficiency. A parathyroid hormone (PTH) value $\leq 9.4 \mathrm{pg} / \mathrm{ml}$ was $84.9 \%$ sensitive and $71.4 \%$ specific to predict PostHypo on the $1^{\text {st }}$ postoperative day. A $50 \%$ reduction of the PTH value on the 1 st postoperative day from the preoperative level could identify patients who develop PostHypo with $76 \%$ sensitivity and $75 \%$ specificity. Conclusion: PTH postoperative measurement and its alteration from the preoperative level can be used to identify patients who are at increased risk to develop PostHypo.
\end{abstract}

This article is freely accessible online.

Correspondence to: Kassiani Kakava, Head and Neck Surgery Department, Metaxa Anti-Cancer Hospital, Botasi 51, 18537 Pireaus, Greece. Tel: +30 2104612529, e-mail: kassianh7882@gmail.com

Key Words: Total thyroidectomy, postsurgical hypocalcemia, acute postsurgical hypoparathyroidism, parathormone.
Total thyroidectomy is generally a safe procedure when performed by experienced surgeons. Potential major complications of thyroid surgery include injury to the recurrent laryngeal nerve, postsurgical hypoparathyroidism (PostHypo) resulting in hypocalcemia, thyrotoxic storm and surgical site infection (1). Among these conditions, PostHypo is the most common one and often the most troubling consequence of thyroid surgery (2). PostHypo is a disorder characterized by hypocalcemia, low or inappropriately normal intact parathyroid hormone (PTH) levels, and often hyperphosphatemia (3). It results from an accidental gland injury, removal of the parathyroid glands, or their devascularization (4). PostHypo may be transient when it recovers within a few weeks or one month after thyroid surgery (5), or chronic when hypoparathyroidism persists for at least six months postoperatively $(6,7)$. The incidence of temporary and permanent post-surgical hypoparathyroidism is estimated between $19-38 \%$ and $0-3 \%$, respectively $(8,9)$.

The aims of this present study were to correlate all the epidemiological and laboratory parameters with PostHypo, and to investigate the potential prognostic factors that are related to the development of PostHypo.

\section{Patients and Methods}

The study was conducted in compliance with the principles of the Declaration of Helsinki and was also approved by the National and Kapodistrian University of Athens Medical School (protocol number 1387/8-12-2015; NCT04146259). Detailed informed consent was signed by all patients enrolled in the study before their involvement.

Patients. A prospective cohort study was performed in 109 consecutive patients who underwent total thyroidectomy, between 
December 2015 and December 2016, at the Head and Neck Surgery Department, at Metaxa Anti-Cancer Hospital of Piraeus, Greece.

All patients were female with a mean age \pm standard deviation (SD) of $50.7 \pm 10.75$ years, they were euthyroid at the time of the thyroid operation and were operated by three different experienced surgeons in our department.

Based on the development of biochemical hypocalcemia on the first postoperative day following total thyroidectomy, $(\mathrm{cCa}<8.4$ $\mathrm{mg} / \mathrm{dl}$ ), subjects were classified into 2 different Groups: i) Group A included 72 patients without PostHypo and ii) Group B included 37 patients who developed PostHypo. Replacement with oral calcium and Vitamin D (VitD) analogues was initiated when the cCa was $\leq 8.4 \mathrm{mg} / \mathrm{dl}$. Patients were subsequently discharged from hospital once clinical manifestations were subsided and normal serum corrected calcium levels were attained.

Inclusion criteria. In general, a total thyroidectomy is performed when there is a suspicion for papillary or medullary thyroid carcinoma (10). Indications for surgery were: i) multinodular goiter with cold nodules $(n=48)$, ii) nodular goiter $(n=28)$, iii) substernal goiter producing pressing symptoms in adjacent tissues $(n=8)$, iv) Graves' disease resistant to therapy ( $n=3)$, and v) a Bethesda result (B) higher or equal to III $(\mathrm{B} \geq \mathrm{III})$ in the pathology report of the fine needle aspiration cytology (FNAC) $(n=22)$. The FNAC results for $\mathrm{B}$ in all patients were: i) BI in 20 patients $(18.35 \%)$, ii) BII in 67 $(61.47 \%)$, iii) BIII in 7 (6.42\%), iv) BIV in $1(0.92 \%)$, v) BV in 10 $(9.17 \%)$, and vi) BVI in $4(3.67 \%)$.

Exclusion criteria. Chronic kidney disease, parathyroid disorders and patients on anti-osteoporosis therapy were excluded from the study, as well as patients with a history of long-term (more than one-month administration) or current corticosteroid use.

Sample testing. Blood collections were performed in the morning following overnight fasting, at 3 different time-points: i) one day before thyroid surgery, ii) on the $1^{\text {st }}$ postoperative day and iii) on the $7^{\text {th }}$ postoperative day. Factors determined were: i) $25(\mathrm{OH}) \mathrm{VitD}$, ii) $\mathrm{PTH}$, iii) corrected calcium (cCa), iv) calcium (Ca), v) phosphorus $(\mathrm{P})$, vi) creatinine, vii) alkaline phosphatase, and viii) albumin. Calcium levels were reported as cCa for albumin levels, using the equation:

$[\mathrm{cCa}]=[\mathrm{Ca}]+(4-[$ albumin $] * 0.8)(1)$

Additional blood samples were taken from the patients in case of symptoms suggestive of hypocalcemia.

All blood collections were centrifuged and serum aliquots were stored at $-70^{\circ} \mathrm{C}$ until tested, except from $\mathrm{Ca}, \mathrm{P}$, creatinine, alkaline phosphatase and albumin measurements, which were directly analyzed on the same day in the laboratory. Total 25(OH)VitD was measured with an Electrochemiluminescence immunoassay on cobas E411 (Roche Diagnostics, Mannheim, Germany). The assay has a sensitivity of $5 \mathrm{ng} / \mathrm{ml}$. The total analytical imprecision of this assay in our laboratory is less than $10 \%$. The bias of the assay was monitored by the participation of our laboratory in the Vitamin D external quality assessment scheme (DEQAS) program. Intact PTH was measured by a second - generation Electrochemiluminescence immunoassay on cobas E411. The assay has a sensitivity of 1.2 $\mathrm{pg} / \mathrm{ml}$. The total analytical imprecision of this assay in our laboratory is less than $3.5 \%$. Serum levels of $\mathrm{Ca}, \mathrm{P}$, albumin,
Table I. Baseline characteristics of the study groups. Group A represents patients without PostHypo and Group B patients with PostHypo.

\begin{tabular}{lccc}
\hline Parameter & Group A $(\mathrm{n}=72)$ & Group B $(\mathrm{n}=37)$ & $p$-Value \\
\hline Age (years) & $52.33 \pm 10.82$ & $47.51 \pm 10.00$ & 0.03 \\
Weight $(\mathrm{kg})$ & $74.68 \pm 16.28$ & $73.78 \pm 14.20$ & 0.77 \\
Height $(\mathrm{cm})$ & $162.71 \pm 6.05$ & $163.03 \pm 4.69$ & 0.24 \\
Body mass index $\left(\mathrm{kg} / \mathrm{m}^{2}\right)$ & $28.22 \pm 5.93$ & $27.42 \pm 5.15$ & 0.49 \\
Menopause (n, \%) & $35(48.61)$ & $12(32.43)$ & 0.15 \\
Creatinine (mg/dl) & $0.70 \pm 0.10$ & $0.67 \pm 0.9$ & 0.11 \\
Ca (mg/dl) & $9.53 \pm 0.37$ & $9.44 \pm 0.42$ & 0.24 \\
Corrected calcium (mg/dl) & $9.17 \pm 0.31$ & $8.99 \pm 0,39$ & 0.01 \\
Albumin (gr/dl) & $4.45 \pm 0.30$ & $4.55 \pm 0.29$ & 0.07 \\
Phosphate (mg/dl) & $3.48 \pm 0.48$ & $3.54 \pm 0.59$ & 0.58 \\
Alkaline phosphatase & $68.27 \pm 18.17$ & $65.95 \pm 21.22$ & 0.55 \\
(IU/l) & & & \\
PTH (pg/ml) & $28.48 \pm 13.54$ & $29.13 \pm 14.87$ & 0.82 \\
25(OH)VitD (ng/ml) & $21.29 \pm 10.32$ & $19.56 \pm 9.03$ & 0.39 \\
\hline
\end{tabular}

PTH: Parathyroid hormone; VitD: vitamin D.

alkaline phosphatase and creatinine were measured using a photometric method on Architect c16000 Clinical Chemistry Analyzer, (Abbott Diagnostics, North Chicago, IL, USA).

Data from the patients' groups, including baseline levels of PTH, $\mathrm{cCa}, 25(\mathrm{OH}) \mathrm{D}$, the first postoperative day absolute values of $\mathrm{P}$ and PTH and \% changes of circulating $\mathrm{PTH}, \mathrm{cCa}, \mathrm{Ca}$ and $\mathrm{P}$ were estimated as follows:

$$
\begin{aligned}
& \Delta \mathrm{PTH}=\left[\left(\mathrm{PTH}_{1}-\mathrm{PTH}_{0}\right) / \mathrm{PTH}_{0}\right]^{*} 100 \\
& \Delta \mathrm{cCa}=\left[\left(\mathrm{cCa}_{1}-\mathrm{cCa}_{0}\right) / \mathrm{ca}_{0}\right]^{*} 100 \\
& \Delta \mathrm{Ca}=\left[\left(\mathrm{Ca}_{1}-\mathrm{Ca}_{0}\right) / \mathrm{Ca}_{0}\right]^{* 100} \\
& \Delta \mathrm{P}=\left[\left(\mathrm{P}_{1}-\mathrm{P}_{0}\right) / \mathrm{P}_{0}\right]^{*} 100, \\
& \text { All values were plotted as ROC curves. }
\end{aligned}
$$

Statistical analysis. Data are presented as mean \pm SD for continuous variables and as frequencies (\%) for categorical variables. Changes of the variables during the observation period were analyzed using one-way analysis of variance (ANOVA) for repeated measurements, while pairwise differences were analyzed using the Bonferroni test. Groups' differences were analyzed with the Analysis of covariance model (ANCOVA) using the group as a factor and the age as a covariate. Bivariate correlations were estimated using the Spearman's rank correlation test. All tests were two-sided and the statistical significance was set at $p<0.05$.

All analyses were carried out using the statistical package SPSS, version 21.00 (IBM Corporation, Somers, NY, USA).

\section{Results}

Baseline demographic characteristics and preoperative biochemical parameters are shown in Tables I and II. The two groups were comparable according to i) weight, ii) height, iii) body mass index and iv) menopausal status. Patients that developed hypocalcemia (Group B) were younger (Group A: $52.3 \pm 10.82$ vs. Group B: $47.51 \pm 10.00$ years old, $p=0.03$ ), and had lower baseline cCa levels as 
Table II. Clinical characteristics of the study groups. Group A refers to patients without PostHypo and Group B to patients with PostHypo.

\begin{tabular}{|c|c|c|c|c|c|}
\hline \multirow[t]{2}{*}{ Parameter } & \multicolumn{2}{|c|}{ Group A } & \multicolumn{2}{|c|}{ Group B } & \multirow[t]{2}{*}{$p$-Value } \\
\hline & $\mathrm{N}=72$ & $66 \%$ & $\mathrm{~N}=37$ & $34 \%$ & \\
\hline \multicolumn{6}{|l|}{$\begin{array}{l}\text { Sonographic } \\
\text { characteristics } \\
\text { preoperative }\end{array}$} \\
\hline Nodular & 16 & $22.2 \%$ & 14 & $37.8 \%$ & 0.115 \\
\hline Multinodular & 56 & $77.8 \%$ & 23 & $62.2 \%$ & \\
\hline \multicolumn{6}{|l|}{ FNA results } \\
\hline I & 13 & $18.05 \%$ & 7 & $18.92 \%$ & 1.00 \\
\hline II & 49 & $68.07 \%$ & 18 & $48.67 \%$ & \\
\hline III & 4 & $5.55 \%$ & 3 & $8.1 \%$ & \\
\hline IV & 0 & $0 \%$ & 1 & $2.7 \%$ & \\
\hline $\mathrm{V}$ & 5 & $6.94 \%$ & 5 & $13.51 \%$ & \\
\hline VI & 1 & $1.39 \%$ & 3 & $8.1 \%$ & \\
\hline \multicolumn{6}{|l|}{$\begin{array}{l}\text { Histopathology } \\
\text { result }\end{array}$} \\
\hline Benign & 42 & $58.3 \%$ & 17 & $45.9 \%$ & 0.310 \\
\hline Malignant & 30 & $41.7 \%$ & 20 & $54.1 \%$ & \\
\hline \multicolumn{6}{|l|}{$\begin{array}{l}\text { Hashimoto } \\
\text { thyreoiditis }\end{array}$} \\
\hline Absent & 52 & $72.2 \%$ & 21 & $56.8 \%$ & 0.178 \\
\hline Present & 20 & $27.8 \%$ & 16 & $43.2 \%$ & \\
\hline \multicolumn{6}{|l|}{$\begin{array}{l}\text { Number of } \\
\text { parathyroid } \\
\text { gland resected in } \\
\text { pathology report }\end{array}$} \\
\hline 0 & 57 & $79.2 \%$ & 20 & $54 \%$ & 0.017 \\
\hline 1 & 13 & $18 \%$ & 14 & $37.8 \%$ & \\
\hline 2 & 2 & $2.8 \%$ & 1 & $2.7 \%$ & \\
\hline 3 & 0 & $0 \%$ & 2 & $5.5 \%$ & \\
\hline \multicolumn{6}{|l|}{$\begin{array}{l}\text { L-thyroxin } \\
\text { therapy } \\
\text { preoperatively }\end{array}$} \\
\hline No & 26 & $36.1 \%$ & 17 & $45.9 \%$ & $>0.05$ \\
\hline Yes & 46 & $63.9 \%$ & 20 & $54.1 \%$ & \\
\hline $\begin{array}{l}\text { Weight of } \\
\text { specimen }\end{array}$ & $23.08 \mathrm{gr}$ & & $24.08 \mathrm{gr}$ & & 0.258 \\
\hline VitD Deficiency & 37 & $51.39 \%$ & 19 & $51.35 \%$ & $>0.05$ \\
\hline
\end{tabular}

FNA: Fine needle aspiration; VitD: vitamin D.

compared with controls (Group A: $9.17 \pm 0.31 \mathrm{mg} / \mathrm{dl} v s$. Group B: $8.99 \pm 0.39 \mathrm{mg} / \mathrm{dl}, p=0.01)$.

All other variables were comparable between the two groups. More than half of all patients (51.4\%) had a $25(\mathrm{OH})$ VitD deficiency $(<20 \mathrm{ng} / \mathrm{ml})$ (Table I).

Concerning the pathology results, the number of parathyroid glands present in the specimens was the only clinical characteristic that showed a statistically significant difference between the two Groups $(p=0.017)$. Specifically, in Group A the number of parathyroid glands found in the specimens was: i) 0 glands in 57 patients $(79.2 \%)$, ii) 1 gland in $13(18 \%)$, iii) 2 glands in $2(2.8 \%)$, iv) 3 glands in no patients $(0 \%)$ while in group $\mathrm{B}$ the corresponding numbers

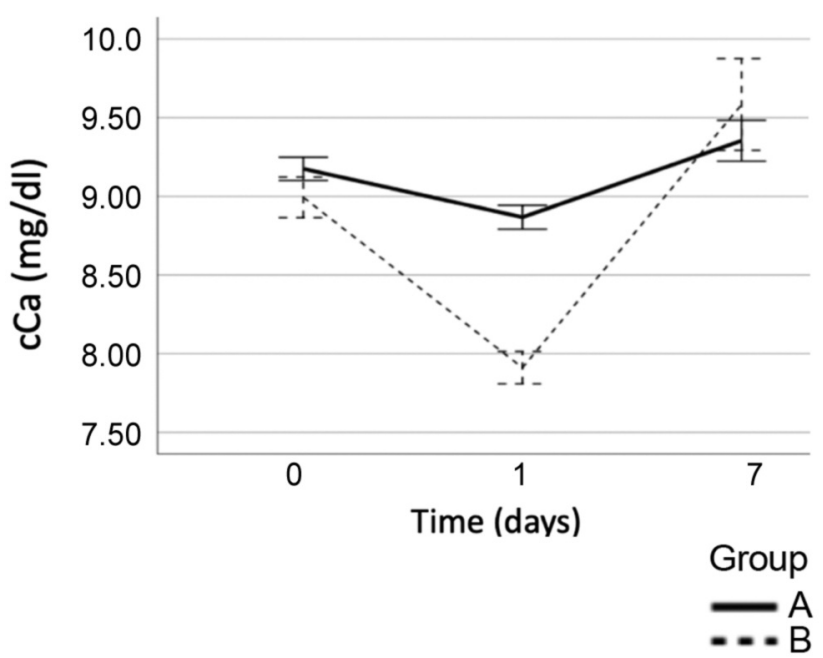

Figure 1. Changes of cCalcium in postoperative period (Group A: Patients without PostHypo, Group B: Patients with PostHypo).

were: i) 0 gland in 20 patients $(54 \%)$, ii) 1 gland in 14 $(37.8 \%)$, iii) 2 glands in $1(2.7 \%)$ and iv) 3 glands in 2 $(5.5 \%)$. None other feature, including preoperative sonographic characteristics, Hashimoto's thyroiditis, FNAC, pathology report and weight of specimen was different between the two Groups, $(p>0.05)$ (Table II).

Changes in serum cCa, P, PTH levels during the observation period. On the $1^{\text {st }}$ postoperative day, the mean cCa dropped to $8.86 \pm 0.32 \mathrm{mg} / \mathrm{dl}$ in Group A and to $7.898 \pm 0.31 \mathrm{mg} / \mathrm{dl}$ in Group B. Patients in Group B had a significantly lower cCa value on the $1^{\text {st }}$ postoperative day compared to group $\mathrm{A}$ $(p<0.001)$. Calcium supplements and VitD analogues were given to patients with PostHypo in Group B in individualized doses, whereas Group A managed to increase their Ca levels after 7 days without the need for oral supplementation. All the patients had higher $\mathrm{cCa}$ levels on the $7^{\text {th }}$ postoperative day, $9.352 \pm 0.55 \mathrm{mg} / \mathrm{dl}$ in Group A and $9.593 \pm 0.87 \mathrm{mg} / \mathrm{dl}$ in Group B, $(p<0.05)$ (Figure 1).

Concerning $\mathrm{P}$ levels, there was no significant difference in the preoperative values between the two groups (Group A: $3.48 \pm 0.48 \mathrm{mg} / \mathrm{dl} v s$ Group B: $3.54 \pm 0.60 \mathrm{mg} / \mathrm{dl}, p=0.58$ ), however, on the $1^{\text {st }}$ postoperative day, $\mathrm{P}$ levels increased to $3.79 \pm 0.72 \mathrm{mg} / \mathrm{dl}$ in Group A and $4.192 \pm 0.62 \mathrm{mg} / \mathrm{dl}$ in Group $\mathrm{B}(p<0.01)$. On the $7^{\text {th }}$ postoperative day $\mathrm{P}$ levels tended to normalize in Group A in contrast with Group B, where a further increase was observed (Group A: $3.7 \pm 0.62 \mathrm{mg} / \mathrm{dl} v \mathrm{~s}$ Group B: $4.44 \pm 0.73 \mathrm{mg} / \mathrm{dl})(p<0.001)$. Patients in Group B had significantly higher $\mathrm{P}$ levels in both days (Figure 2).

Mean preoperative PTH levels were comparable between the two Groups, (Group A: 28.49 $\pm 13.54 \mathrm{pg} / \mathrm{dl}$ vs Group B: $29.13 \pm 14.88 \mathrm{pg} / \mathrm{dl}, p=0.82)$. On the first postoperative day, 


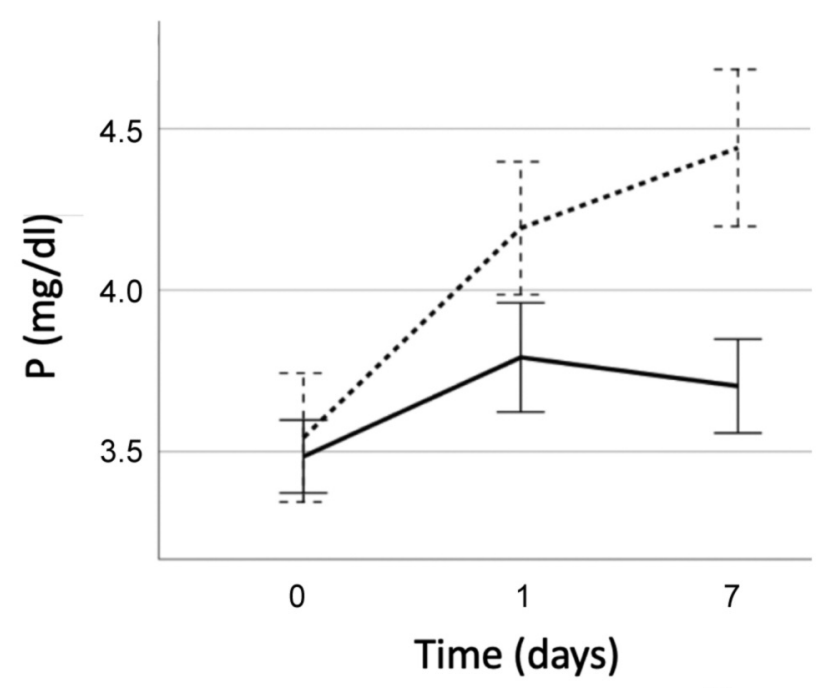

Group

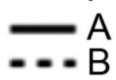

Figure 2. Changes in phosphorus during the postoperative period (Group A: Patients without PostHypo, Group B: Patients with PostHypo).

PTH was reduced to $18.85 \pm 10.83 \mathrm{pg} / \mathrm{dl}$ in Group A, and to $9.94 \pm 11.92 \mathrm{pg} / \mathrm{dl}$ in Group B $(p<0.001)$. On the $7^{\text {th }}$ postoperative day PTH levels increased in Group A in contrast with Group B where a further reduction was noted: Group A: 20.04 $\pm 12.87 \mathrm{pg} / \mathrm{ml}$ vs. Group B: $8.91 \pm 9.35 \mathrm{pg} / \mathrm{ml}$ (Figure 3).

In an attempt to determine the optimal values with the best combination of specificity and sensitivity, receiver operating characteristic (ROC) curves were performed. Preoperative values of cCa, Phosphorus, PTH, 25(OH)VitD as well $\mathrm{P}$ and $\Delta \mathrm{P}$ from first day post operation were poor predictors of differentiation between the two Groups, as shown by the Area Under the Curve (AUC) at $\leq 0.7$ for all. On the other hand, on the $1^{\text {st }}$ postoperative day PTH, $\triangle \mathrm{PTH}, \Delta \mathrm{cCa}$ and $\triangle \mathrm{Ca}$ were acceptable as AUC was $>0.8$ for all of them. The best cut-off for PTH was found to be $9.4 \mathrm{pg} / \mathrm{ml}$ with a sensitivity of $84.9 \%$ and a specificity of $71.4 \%$, (AUC $=0.806,95 \% \mathrm{CI}=0.706-0.906, p=0.05$ ). Furthermore, for $\triangle \mathrm{PTH}$, the ROC curve indicated that a $50 \%$ reduction on $1^{\text {st }}$ postoperative day PTH from the preoperative level as the best cut-off, with a sensitivity of $76 \%$ and a specificity of $75 \% \quad(\mathrm{AUC}=0.825,95 \% \mathrm{CI}=0.733-0.917, p=0.047) . \quad$ In addition, for the $\Delta \mathrm{cCa}$ levels, the ROC curve indicated a $7 \%$ decrease in cCa one day post operation as the best cut - off, with a sensitivity of $87 \%$ and a specificity of $83 \%$ (AUC $=0.922,95 \% \mathrm{CI}=0.863-0.982, p=0.030$ ). Lastly, the best cut-off for $\Delta \mathrm{Ca}$ concentration was found to be a reduction of $11.35 \%$ in $\mathrm{Ca} 1^{\text {st }}$ day post operation from preoperatively, with a sensitivity of $90 \%$ and a specificity of $83 \%$ (AUC $=0.90,95 \% \mathrm{CI}=0.835-0.966, p=0.033$ ). The clinical

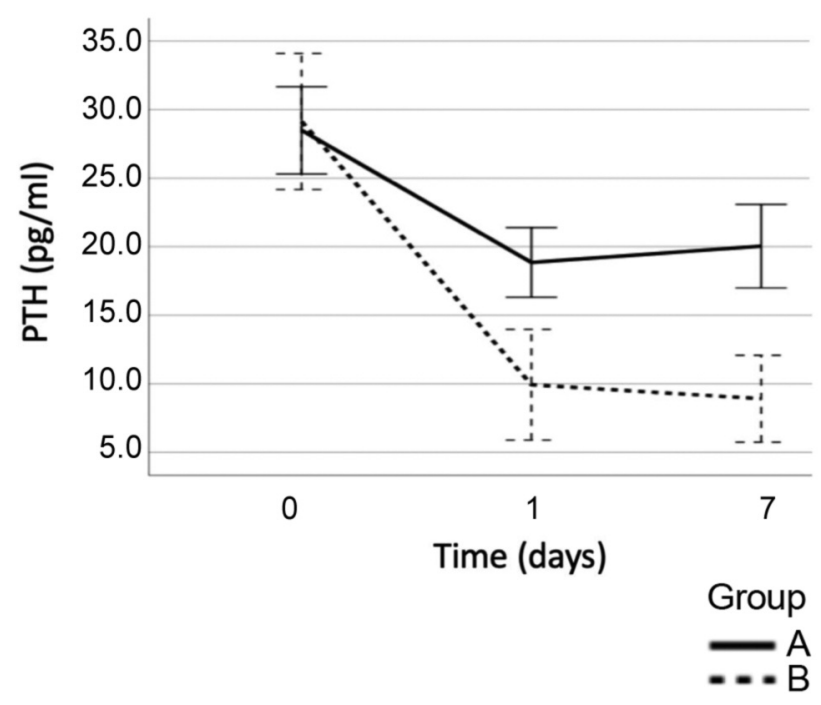

Figure 3. Changes in PTH during the postoperative period (Group A: Patients without PostHypo, Group B: Patients with PostHypo).

implementation of all these values is that the attending physician can observe them closely and, accordingly, can predict if a patient is a candidate for the development of symptoms related to PostHypo.

\section{Discussion}

During the past few decades there has been considerable controversy concerning the type and time of measurements performed to predict transient or permanent post-operative hypoparathyroidism. Different researchers have tried to identify a useful method to predict which patients should be administered supplemented calcium before safe hospital discharge.

Potential advantages associated with an earlier discharge are i) cost savings, ii) improved patient convenience, and iii) lower exposure to nosocomial pathogens. Hypocalcemia usually becomes noticeable between 24 and $48 \mathrm{~h}$ after thyroidectomy and calcium is generally measured at 6 to 12 $\mathrm{h}$ intervals (11). The patient can be discharged when normal corrected calcium level is achieved and an upward trend of corrected calcium is observed.

According to these issues, our study mainly focuses on the correlation of all the biochemical and demographical risk factors with the development of PostHypo and the comparison of our results with the latest data from the literature. Moreover, we suggested the optimal PTH, $\triangle \mathrm{PTH}$, $\Delta \mathrm{cCa}$ and $\triangle \mathrm{Ca}$ values, according to ROC curves that can differentiate the two groups of patients.

Our study confirmed that a lower preoperative calcium level was a risk factor for PostHypo, as patients in Group B 
had significantly lower $\mathrm{cCa}$ levels before the thyroid operation. The same finding has been confirmed by other studies in the literature (12-18). Similarly, a low postoperative $\mathrm{Ca}$ has been related to PostHypo, $(14,15,19-$ 28) as observed also in our study. Additionally, a larger decline in postoperative Calcium is also related to PostHypo $(15,20,21,25,29)$.

Moreover, there is no consensus in the literature regarding the best time-point to test the PTH levels. The intraoperative PTH assay is widely used during parathyroid surgery (29). Intraoperative is defined as starting at time zero, which is the moment of gland excision, to skin closure at the end of the thyroid operation. The half-life of PTH is 3 minutes and its measurement is a very accurate predictor of subsequent hypocalcemia (30). It appears to be no disadvantage using intraoperative PTH measurement versus that obtained postoperatively to guide initial clinical management of serum calcium (31). In our study, PTH following surgery differed significantly between the two groups of patients. A low PTH after surgery has been related to PostHypo in many similar studies in the literature $(14,19,20-24,31-39)$ as well as a large decline of postoperative PTH $(19,32-35,40,41)$. Additionally, a great percentage $(51.4 \%)$ of patients from both groups in our study had a Vitamin D deficiency with values lower than $20 \mathrm{ng} / \mathrm{ml}$. Many other studies have confirmed the important role of Vitamin D sufficiency before thyroid surgery for the avoidance of PostHypo $(37,42,43)$. A high phosphorus level following thyroidectomy is also related to the development of PostHypo in the present study, as found previously $(19,38)$.

In our study, hypocalcemia was significantly more common in younger patients. Previous studies have published conflicting results with respect to age as a risk factor for the development of PostHypo (6, 14, 42, 44-46). Malignant pathology was not related to PostHypo in our study, although other studies have confirmed this correlation $(15,47,48)$. Also, in our study the enlarged thyroid specimen was not related significantly with the risk of PostHypo, whereas positive correlation between thyroidectomy specimens and the risk of PostHypo has been previously concluded (46). Finally, the number of identified resected parathyroid glands from the pathology analysis was related to PostHypo, in agreement with other studies in the literature (49).

Our study confirmed that PTH, $\triangle \mathrm{PTH}, \Delta \mathrm{cCa}$ and $\Delta \mathrm{Ca}$ are parameters that best characterize patients who have a high risk for developing PostHypo. The preoperative as well as the postoperative values can be used in the clinical practice to predict which patients can be discharged from the hospital sooner and which ones should be more closely monitored for symptoms related to postsurgical hypocalcemia. We tried to predict more accurately using the ROC curves the value of $\mathrm{PTH}, \triangle \mathrm{PTH}, \triangle \mathrm{cCa}$ and $\triangle \mathrm{Ca}$ levels that could safely differentiate between symptomatic and asymptomatic patients. Consequently, although there are not absolute cutoff values to differentiate between the two groups, an important finding of our study was that a PTH level less than $9.4 \mathrm{pg} / \mathrm{ml}$ was $84.9 \%$ sensitive and $71.4 \%$ specific for predicting PostHypo. A drop in the parathormone value by more than $50 \%$ of the preoperative level on the $1^{\text {st }}$ postoperative day had a $76 \%$ sensitivity and a $75 \%$ specificity predicting PostHypo. Accordingly, when examining $\mathrm{Ca}$ reduction without the correction of albumin, an $11.35 \%$ decrease of $\mathrm{Ca}$ between the $1^{\text {st }}$ postoperative day and the preoperative value had the best combination of sensitivity (90\%) and specificity (83\%). Finally, a reduction of $7 \%$ in the corrected Calcium on the $1^{\text {st }}$ postoperative day compared to the pre-operation value could identify patients who develop PostHypo with $87 \%$ sensitivity and $83 \%$ specificity.

Furthermore, according to our study the lower preoperative values of $\mathrm{cCa}$ were positively related to PostHypo, while a great percentage of patients had a VitD deficiency, which is common in Greece throughout the year (50). Therefore, we suggest a routine control of $\mathrm{Ca}$ metabolism for all patients who are candidates for thyroidectomy. A possible supplementation of calcium per os preoperatively could also play a protective role, while $25(\mathrm{OH})$ VitD should also be tested in patients preoperatively. In case the patient is $25(\mathrm{OH}) \mathrm{VitD}$ deficient $(<20 \mathrm{ng} / \mathrm{ml})$, a high dose of VitD could be considered. Until today, there are no consistent data concerning the preoperative VitD therapy on postoperative calcium $(51,52)$ and further studies are required.

Our study presents some limitations concerning the number of patients and the fact that there were recruited mostly from a single center. Also, only female patients were included so as to correlate the PostHypo to the calcium metabolism. Women are more often affected from diseases that are related to calcium metabolism, such as hyper- and hypoparathyroidism as well as osteoporosis $(53,54)$.

In conclusion, no absolute values of PTH or $\mathrm{Ca}$ were identified in our patients that could differentiate them according to their risk of developing hypocalcemia. Moreover, there is no indication about the optimal time point to control PTH and $\mathrm{Ca}$ and the two time points of 24 hours and 7 days are used in more often in clinical practice (3). Our study focuses in all the parameters that are related to PostHypo, including clinical characteristics as well as biochemical and hormonal results. These findings can have a clinical implementation in the everyday practice for patients undergoing total thyroidectomy, despite the fact that there is not a clear cut-off to differentiate between the two groups of patients. Importantly, the clinical decisions should be personalized for each patient separately, and all the clinical and laboratory parameters should be assessed on their own 
and in combination in order to find the patients who are at a greater risk for postsurgical hypocalcemia. Finally, further studies including more patients of both sexes are required to identify patients at a high risk of PostHypo at an early stage.

\section{Conflicts of Interest}

The Authors report no conflicts of interest regarding this study.

\section{Authors' Contributions}

All Authors contributed to the design and implementation of the research, the analysis of the results and the writing of the manuscript. KK carried out the experiment and the contact with the patients. KK and GP wrote the manuscript and performed the numerical calculations for the suggested experiment with support from ST and TK. Moreover, KM performed the laboratory measurements. All Authors discussed the results and contributed to the final manuscript.

\section{Acknowledgements}

The Authors would like to thank all the patients for the participation in this study and the Medical Doctors of the Head and Neck Department of Surgery at Metaxa Anti-Cancer Hospital: N. Petridis, G. Tasopoulos, P. Sarof, I. Karelas, P. Stampouloglou as well as V. Villiotou from the Biochemical Department for their valuable contribution.

\section{References}

1 Chahardahmasumi E, Salehidoost R, Amini M, Aminorroaya A, Rezvanian H, Kachooei A, Iraj B, Nazem M and Kolahdoozan M: Assessment of the early and late complication after thyroidectomy. Adv Biomedical Res 8: 14, 2019. DOI: 10.4103/ abr.abr_3_19

2 Del Rio P, Rossini M, Montana CM, Viani L, Pedrazzi G, Loderer T and Cozzani F: Postoperative hypocalcemia: Analysis of factors influencing early hypocalcemia development following thyroid surgery. BMC Surgery 18: 25, 2019. DOI: 10.1186/s12893-019-0483-y

3 Kakava K, Tournis S, Papadakis G, Karelas I, Stampouloglou P, Kassi E, Triantafillopoulos I, Villiotou V and Karatzas T: Postsurgical hypoparathyroidism: A systematic review. In Vivo 30(3): 171-179, 2016. PMID: 27107072.

4 Wang YH, Bhandari A, Yang F, Zhang W, Xue LJ, Liu HG, Zhang XH and Chen CZ: Risk factors for hypocalcemia and hypoparathyroidism following thyroidectomy: A retrospective Chinese population study. Cancer Manag Res 9: 627-635, 2017. PMID: 29180898. DOI: $10.2147 /$ CMAR.S148090

5 Villarroya-Marquina I, Sancho J, Lorente-Poch L, GallegoOtaegui L and Sitges-Serra A: Time to parathyroid function recovery in patients with protracted hypoparathyroidism after total thyroidectomy. Eur J Endocrinol 178(1): 103-111, 2018. PMID: 29066572. DOI: 10.1530/EJE-17-0589

6 Komissarenko YI, Bobryk MI, Sidorova IV and Burka OA: Current European Guidelines on the Management of Chronic Hypoparathyroidism in Adults. According to the Materials of the $17^{\text {th }}$ Congress of the European Society of Endocrinology, Dublin, Ireland, 16-20 May 2015. Int J Endocrinol 5: 69, 2015. DOI: 10.22141/2224-0721.5.69.2015.75092

7 Starck BC, Bimston DN, Bodenner DL, Brett EM, Dralle H, Orloff LA, Pallota J, Snyder S, Wong R and Randolph G: American Association of Clinical Endocrinologists and American College of Endocrinology Disease State Clinical Review: Postoperative hypoparathyroidism - Definitions and management. Endocr Pract 21(6): 674-685, 2015. PMID: 26135962. DOI: $10.4158 /$ EP14462.DSC

8 Edafe O, Antakia R, Laskar N, Uttley L and Balasubramanian SP: Systematic review and meta-analysis of predictors of postthyroidectomy hypocalcaemia. Br J Surg 101(4): 307-320, 2014. PMID: 24402815. DOI: 10.1002/bjs.9384

9 Costa AG, Cremens S, Rubin MR, McMahon DJ, Sliney J, Lazaretti-Castro M, Silverberg S and Bilezikian J: Circulating sclerostin in disorders of parathyroid gland function. J Clin Endocrinol Metab 96(12): 3804-3810, 2011. PMID: 21937621. DOI: $10.1210 /$ jc. $2011-0566$

10 Papadakis G, Keramidas I, Triantafillou E, Kanouta F, Pappa T, Kaltzidou V, Tertipi A, Iordanidou L, Trivizaki E, Vecchini G, Villiotou V and Pappas A: Association of basal and calciumstimulated calcitonin levels with pathological findings after total thyroidectomy. Anticancer Res 35(7): 4251-4258, 2015. PMID: 26124386.

11 AlQahtani A, Parsyan A, Payne R and Tabah R: Parathyroid hormone levels 1 hour after thyroidectomy: an early predictor of postoperative hypocalcemia. Can J Surg 57(4): 237-240, 2014. PMID: 25078927. DOI: 10.1503/cjs.008013

12 Sieniawski K, Kaczka K, Paduszynska K, Fendler W, Tomasik $\mathrm{B}$ and Pomorski L: Early predictors of post-thyroidectomy hypoparathyroidism. Pol Przegl Chir 88(6): 305-314, 2016. PMID: 28141553. DOI: $10.1515 /$ pjs-2016-0069

13 Sitges-Serra A, Ruiz S, Girvent M, Manjon H, Duenas JP and Sancho JJ: Outcome of protracted hypoparathyroidism after total thyroidectomy. Br J Surg 97: 1687-1695, 2010. DOI: 10.1002/ bjs.7219

14 Gentileschi P, Gacek IA, Manzelli A, Coscarella G, Sileri P, Lirosi F, Camperchioli I, Stolfi VM and Gaspari AL: Early (1 hour) post-operative parathyroid hormone (PTH) measurement predicts hypocalcaemia after thyroidectomy: A prospective casecontrol single-institution study. Chir Ital 60(4): 519-528, 2008. PMID: 18837252.

15 Lang BHH, Yih PCL and Ng KK: A prospective evaluation of quick intraoperative parathyroid hormone assay at the time of skin closure in predicting clinically relevant hypocalcemia after thyroidectomy. World J Surg 36(6): 1300-1306, 2012. DOI: 10.1007/s00268-012-1561-9

16 Amir A, Sands NB, Tamilia M, Hier MP, Black MJ and Payne R: Preoperative serum calcium levels as an indicator of postthyroidectomy hypocalcemia. J Otolaryngol Head Neck Surg 39(6): 654-658, 2010. PMID: 21144360.

17 Bergenfelz A, Jansson S, Kristoffersson A, Martensson H, Reihner E, Wallin G and Lausen I: Complications to thyroid surgery: Results as reported in a database from a multicenter audit comprising 3.660 patients. Langenbecks Arch Surg 393(5): 667-673, 2008. PMID: 18633639. DOI: 10.1007/s00423-0080366-7

18 Ali S, Yu C, Palmer FL, Ganly I, Shaha A, Shah JP, Kattan MWand Patel SG: Nomogram to aid selection of patients for 
short-stay thyroidectomy based on risk of postoperative hypocalcemia. Arch Otolaryngol Head Neck Surg 137(11): 11541160, 2011. PMID: 22106243. DOI: 10.1001/archoto.2011.189

19 Cavicchi O, Piccin O, Caliceti U, Fernandez IJ, Bordonaro C, Saggese D and Ceroni AR: Accuracy of PTH assay and corrected calcium in early prediction of hypoparathyroidism after thyroid surgery. Otolaryngol Head Neck Surg 138(5): 594-600, 2008. PMID: 18439464. DOI: 10.1016/j.otohns.2008.01.016

$20 \mathrm{Kim}$ JH, Chung MK and Son YI: Reliable early prediction for different types of post-thyroidectomy hypocalcemia. Clin Exp Otorhinolaryngol 4(2): 95-100, 2011. PMID: 21716957. DOI: 10.3342/ceo.2011.4.2.95

21 Graff AT, Miller FR, Roehm CE and Prihoda TJ: Predicting hypocalcemia after total thyroidectomy: Parathyroid hormone levels vs. serial calcium levels. Ear Nose Throat J 89(9): 462465, 2010. PMID: 20859873.

22 Al-Dhahri SF, Al-Ghonaim YA and Terkawi AS: Accuracy of postthyroidectomy parathyroid hormone and corrected calcium levels as early predictors of clinical hypocalcemia. J Otolaryngol Head Neck Surg 39(4): 342-348, 2010. PMID: 20642997.

23 Proczko-Markuszewska M, Kobiela J, Stefaniak T, Lachinski AJ and Sledzinski Z: Postoperative PTH measurement as a predictor of hypocalcaemia after thyroidectomy. Acta Chir Belg 110(1): 40-44, 2010. PMID: 20306908. DOI: 10.1080/00015458. 2010.11680563

24 Asari R, Passler C, Kaczirek K, Scheuba C and Niederle B: Hypoparathyroidism after total thyroidectomy: $\alpha$ prospective study. Arch Surg 143(2): 132-137; discussion 138, 2008. PMID: 18283137. DOI: 10.1001/archsurg.2007.55

25 Lazard D, Godiris-Petit G, Wagner I, Sarfati E and Chabolle F: Early detection of hypocalcemia after total/completion thyroidectomy: Routinely usable algorithm based on serum calcium level. World J Surg 36(11): 2590-2597, 2012. PMID: 22855216. DOI: $10.1007 / \mathrm{s} 00268-012-1727-5$

$26 \mathrm{Wu} \mathrm{SD}$ and $\mathrm{Gao} \mathrm{Li}$ : Is routine calcium supplementation necessary in patients undergoing total thyroidectomy plus neck dissection. Surg Today 41(2): 183-188, 2011. PMID: 21264752. DOI: $10.1007 / \mathrm{s} 00595-010-4230-3$

27 Kara M, Telioglou G, Krand O, Fersahoglu T, Berber I, Erdogdu E, Ozel L and Titiz MI: Predictors of hypocalcemia occuring after a total/near total thyroidectomy. Surg Today 39(9): 752757, 2009. PMID: 19779770. DOI: 10.1007/s00595-009-39571

28 Pfeiderer AG, Ahmad N, Draper MR, Vrotsou K and Smith WK: The timing of calcium measurements in helping to predict temporary and permanent hypocalcaemia in patients having completion and total thyroidectomies. Ann R Coll Surg Engl 91(2): 140-146, 2009. PMID: 19317937. DOI: 10.1308/ $003588409 \times 359349$

29 Starck BC, Moore E, Spencer H, Medvedev S and Bodenner D: Outpatient thyroid surgery data from the University Health System (UHC) consortium. Otolaryngol Head Neck Surg 148(5): 740-745, 2013. PMID: 23401254. DOI: 10.1177/0194599813477823

30 Leiker AJ, Yen TWF, Eastwood DC, Doffek KM, Szabo A, Evans DB and Wang TS: Factors that influence parathyroid hormone half-life: Are new intraoperative criteria needed? JAMA Surg 148(7): 602-606, 2013. PMID: 23677330. DOI: 10.1001/jamasurg.2013.104

31 Lee DR, Hinson AM, Siegel ER, Steelman SC, Bodenner DL and Starck BC: Comparison of intraoperative versus postoperative parathyroid hormone levels to predict hypocalcemia earlier after total thyroidectomy. Otolaryngol Head Neck Surg 153(3): 343-349, 2015. PMID: 26209077. DOI: $10.1177 / 0194599815596341$

32 Vanderlei FAB, Vieira JGH, Hojaij FC, Cervantes O, Kunii IS, Ohe MN, Santos RO and Abrahao M: Parathyroid hormone: an early predictor of symptomatic hypocalcemia after total thyroidectomy. Arq Bras Endocrinol Metab 56(3): 168-172, 2012. DOI: $10.1590 /$ S0004-27302012000300003

33 Lecerf P, Orry D, Perrodeau E, Lhommet C, Charretier C, Mor C, Valat C, Bourlier P and Calan L: Parathyroid hormone decline 4 hours after total thyroidectomy accurately predicts hypocalcemia. Surgery 152(5): 863-868, 2012. PMID: 22657727. DOI: 10.1016/j.surg.2012.03.011

34 Toniato A, Bochin IM, Piotto A, Pelizzo M and Sartori P: Thyroidectomy and parathyroid hormone: Tracing hypocalcemia-prone patients. Am J Surg 196(2): 285-258, 2008. PMID: 18466858. DOI: 10.1016/j.amjsurg.2007. 06.036

35 Chapman DB, French CC, Leng X, Browne D, Waltonen JD and Sullivan CA: Parathyroid hormone early percent change: An individualized approach to predict postthyroidectomy hypocalcemia. Am J Otolaryngol 33(2): 216-220, 2012. PMID: 21899924. DOI: 10.1016/j.amjoto.2011.06.004

36 Costanzo M, Marziani A, Condorelli F, Migliore M and Cannizzaro MA: Post-thyroidectomy hypocalcemic syndrome: Predictive value of early PTH. Preliminary results. Ann Ital Chir 81(4): 301-305, 2010. PMID: 21319702.

37 Kirkby-Bott J, Markogiannakis H, Skandarajah A, Cowan M, Fleming B and Palazzo F: Preoperative vitamin D deficiency predicts postoperative hypocalcemia after total thyroidectomy. World J Surg 35(2): 324-330, 2011. PMID: 21153820. DOI: 10.1007/s00268-010-0872-y

38 Sam AH, Dhillo WS, Donaldson M, Moolla A, Meeran K, Tolley NS and Palazzo FF: Serum phosphate predicts temporary hypocalcaemia following thyroidectomy. Clin Endocrinol 74(3): 388-393, 2011. PMID: 21143616. DOI: 10.1111/j.13652265.2010.03949.x

39 Hermann M, Ott J, Promberger R, Kober F, Karik M and Freissmuth M: Kinetics of serum parathyroid hormone during and after thyroid surgery. Br J Surg 95(12): 1480-1487, 2008. PMID: 18991283. DOI: 10.1002/bjs.6410

40 Kovacevic B, Ignjatovic M, Cuk V, Zivaljevic V and Paunovic I: Early prediction of symptomatic hypocalcemia after total thyroidectomy. Acta Chir Belg 111(5): 303-307, 2011. PMID: 22191132.

41 Sands N, Young J, MacNamara E, Black MJ, Tamilia M, Hier MP and Payne RJ: Preoperative parathyroid hormone levels as a predictor of postthyroidectomy hypocalcemia. Otolaryngol Head Neck Surg 144(4): 518-521, 2011. PMID: 21493227. DOI: $10.1177 / 0194599810395114$

42 Erbil Y, Barbaros U, Temel B, Turkoglu U, Issever H, Bozbora A, Ozarmagan S and Tezelman S: The impact of age, Vitamin $\mathrm{D}_{(3)}$, level, and incidental parathyroidectomy on postoperative hypocalcemia after total or near total thyroidectomy. Am J Surg 197(4): 439-446, 2009. PMID: 19324110. DOI: 10.1016/j. amjsurg.2008.01.032

43 Erbil Y, Ozbey NC, Sari S, Unalp HR, Agcaoglu O, Ersoz F, Issever $\mathrm{H}$ and Ozarmagan $\mathrm{S}$ : Determinants of postoperative hypocalcemia in vitamin D-deficient Graves' patients after total 
thyroidectomy. Am J Surg 201(5): 685-691, 2011. PMID: 21545922. DOI: 10.1016/j.amjsurg.2010.04.030

44 Erbil Y, Bozbora A, Ozbey N, Issever H, Aral F, Ozarmagan S and Tezelman S: Predictive value of age and serum parathormone and Vitamin $\mathrm{D}_{3}$ levels for postoperative hypocalcemia after total thyroidectomy for nontoxic multinodular goiter. Arch Surg 142(12): 1182-1187, 2007. PMID: 18086985. DOI: 10.1001/archsurg.142.12.1182

45 Cho JN, Park WS and Min SY: Predictors and risk factors of hypoparathyroidism after total thyroidectomy. Int J Surg 34: 4752, 2016. PMID: 27554178. DOI: 10.1016/j.ijsu.2016.08.019

46 Hallgrimsson P, Nordenstrom E, Almquist M and Bergenfelz AOJ: Risk factors for medically treated hypocalcemia after surgery for Graves' disease: A Swedish multicenter study of 1.157 patients. World J Surg 36(8): 1933-1942, 2012. PMID: 22476788. DOI: $10.1007 / \mathrm{s} 00268-012-1574-4$

47 Roh JL and Park CIl: Intraoperative parathyroid hormone assay for management of patients undergoing total thyroidectomy. Head Neck 28(11): 990-997, 2006. PMID: 16823862. DOI: 10.1002/hed.20444

48 Del Rio P, Arcuri MF, Ferreri G, Sommaruga L and Sianesi M: The utility of serum PTH assessment 24 hours after total thyroidectomy. Otolaryngol Head Neck Surg 132(4): 584-586, 2005. PMID: 15806050. DOI: 10.1016/j.otohns.2005.01.009

49 Paek SH, Lee YM, Min SY, Kim SW, Chung KW and Youn YK: Risk factors of hypoparathyroidism following total thyroidectomy for thyroid cancer. World J Surg 37(1): 94-101, 2013. PMID: 23052805. DOI: 10.1007/s00268-012-1809-4

50 Papadakis G, Keramidas I, Kakava K, Pappa T, Villiotou V, Triantafillou E, Drosou A, Tertipi A, Kaltzidou V and Pappas A: Seasonal variation of serum vitamin D among Greek female patients with osteoporosis. In Vivo 29(3): 409-413, 2015. PMID: 25977390
51 Lin Y, Ross HL, Raeburn CD, DeWitt PE, Albuja-Cruz M, Jones EL and McIntyre Jr RC: Vitamin D deficiency does not increase the rate of postoperative hypocalcemia after thyroidectomy. Am J Surg 204(6): 888-893; Discussion 893-894, 2012. PMID: 23231931. DOI: 10.1016/j.amjsurg.2012.10.10.001

52 Rolighed L, Rejnmark L, Sikjaer T, Heickendorff L, Vestergaard P, Mosekilde L and Christiansen P: Vitamin D treatment in primary hyperparathyroidism: A Randomized placebo controlled trial. J Clin Endocrinol Metab 99(3): 1072-1080, 2014. PMID: 24423366. DOI: 10.1210/jc.2013-3978

53 Shah VN, Bhadada SK, Bhansali A, Behera A, Mittal BR and Bhavin V: Influence of age and gender on presentation of symptomatic primary hyperparathyroidism. J Postgrad Med 58(2): 107-111, 2012. PMID: 22718053. DOI: 10.4103/00223859.97171

54 Vodopivec DM, Silva AM, Garcia-Banigan DC, Christakis I, Stewart A, Schwarz K, Hussey CS, Bassett R and Perrier ND: Gender differences in bone mineral density in patients with sporadic primary hyperparathyroidism. Endocrinol Diabetes Metab 1(4): e00037, 2018. PMID: 30815565. DOI: 10.1002/ edm2.37

Received June 12, 2020

Revised July 2, 2020

Accepted July 9, 2020 